\title{
Contribution of DNA barcoding to the study of the bees (Hymenoptera: Apoidea) of Canada: progress to date
}

\author{
Cory S. Sheffield, ${ }^{1}$ Jennifer Heron, Jason Gibbs, Thomas M. Onuferko, Ryan Oram, \\ Lincoln Best, Nicholai deSilva, Sheila Dumesh, Alana Pindar, Genevieve Rowe
}

\begin{abstract}
Bees (Hymenoptera: Apoidea, Apiformes) are taxonomically and ecologically diverse, with a wide range of social complexity, nesting preferences, floral associations, and biogeographic restrictions. A Canadian bee checklist, greatly assisted by the gene-assisted approach of DNA barcoding, is nearing completion. Previous evaluation of bee diversity in Canada, assisted by DNA barcoding, was restricted to Nova Scotia, which contains about $25 \%$ of the bee species in the country. Here, we summarise efforts to date to build a comprehensive DNA barcode library supporting bee taxonomic studies in Canada, consisting of more than 12500 barcode-compliant sequences yielding 811 distinct barcode index numbers (BINs). This appears to represent $\sim 95 \%$ of the 856 bee species presently recorded from Canada, but comparison with known morphological species in each genus shows that some genera are still under-sampled or may contain cryptic taxa, with much taxonomic work still to be done on bees in Canada. This is particularly true within the taxonomically difficult genera Andrena Fabricius (Andrenidae), Hylaeus Fabricius (Colletidae), Melissodes Latreille (Apidae), Nomada Scopoli (Apidae), Osmia Panzer (Megachilidae), and Sphecodes Latreille (Halictidae). DNA analysis will likely be a key asset in resolving bee taxonomic issues in Canada in the future, and to date has even assisted studies of well-known bee taxa. Here we present summaries of our results, and discuss the use of DNA barcoding to assist future taxonomic work, faunal lists, and ecological studies.
\end{abstract}

\section{Introduction}

Bees (Hymenoptera: Apoidea) are well known for their role as pollinators, and have become the focus of much recent attention as populations are undergoing declines globally (e.g., Committee on the Status of Pollinators in North America 2007; Vamosi et al. 2016). Bees are a diverse taxon with estimates of over 20000 species worldwide (Michener 2007; Ascher and Pickering 2017), with new species being described regularly, including 22 in Canada since 2010 (Gibbs 2010; Rehan and Sheffield 2011; Gibbs et al. 2013;
Williams et al. 2016). Brown and Paxton (2009) stressed that alpha taxonomy, in particular lack of taxonomic expertise and resources, is one of the major factors limiting ability to conserve bees, since being able to accurately identify species and link them to specific habitats, crops or other plants they pollinate and/or the communities they service is critical for conserving them. However, taxonomic and faunistic knowledge of Canadian bees is incomplete for various reasons (see Sheffield et al. 2009, 2014; Droege et al. 2010), including the large number of poorly studied taxa, and the large size of the country resulting in many areas

Received 17 April 2017. Accepted 24 August 2017. First published online 6 October 2017.

C.S. Sheffield, ${ }^{\mathbf{1}}$ Royal Saskatchewan Museum, 2340 Albert Street, Regina, Saskatchewan, S4P 2V7, Canada

J. Heron, British Columbia Ministry of Environment and Climate Change Strategy, Species Conservation Science Unit, Surrey, British Columbia, V3R 1E1, Canada

J. Gibbs, Department of Entomology, University of Manitoba, Winnipeg, Manitoba, R3T 2N2, Canada

T.M. Onuferko, N. deSilva, S. Dumesh, G. Rowe, Department of Biology, York University, Toronto, Ontario, M3J 1P3, Canada

R. Oram, Royal Saskatchewan Museum, 2340 Albert Street, Regina, Saskatchewan, S4P 2V7, Canada; and Department of Biology, University of Regina Faculty of Science, Regina, Saskatchewan, S4S 0A2, Canada

L. Best, Department of Biological Sciences, University of Calgary, Calgary, Alberta, T2N 1N4, Canada

A. Pindar, School of Environmental Studies, University of Guelph, Guelph, Ontario, N1G 2W1, Canada

${ }^{1}$ Corresponding author (e-mail: Cory.Sheffield@gov.sk.ca)

Subject editor: Donna Giberson.

doi: $10.4039 /$ tce. 2017.49 
being poorly sampled. One challenge is underfunding of taxonomic training and research in general, including in Canada (Packer et al. 2009 b), potentially contributing to slow rates of species discovery and taxonomic revisions (i.e., keys, descriptions and other tools for the identification of all species within a given taxon, including those already described) (see Carvalho et al. 2014). This taxonomic impediment ultimately affects many ecological studies and conservation strategies for bees (e.g., Sheffield et al. 2016), though is even more of an issue for other taxa (e.g., Maurer 2000) that have not received the same level of attention.

Danks (1979) reviewed the diversity of terrestrial arthropods in Canada as an early initiative of the Biological Survey of Canada, this work considered one of the many outstanding achievements of the Biological Survey of Canada (Danks 2016), this issue celebrating its 40th anniversary. That report (Danks 1979) showed that the arthropod fauna was poorly documented, and pointed out that the 29975 reported insect species likely represented only about half of the total expected for Canada. Since then, taxonomic advances (including new molecular taxonomy tools) have improved the knowledge base for many groups. For example, Hebert et al. (2016) used DNA barcoding to estimate more than 94000 insect species in Canada, about a 58\% increase over Danks (1979) estimate, with Diptera and Hymenoptera (especially Parasitica) being "unexpectedly diverse" and in general poorly known.

In the Hymenoptera superfamily Apoidea, which includes the bees (Apiformes), 800 species are currently known from Canada (Sheffield et al. 2014), an increase of about 50 species since the estimates in Danks (1979; 746 species, though 231 more were predicted). No national checklist of bees for Canada has ever been completed, though regional lists for Nova Scotia (Sheffield et al. 2003), Newfoundland (Hicks 2009), and the Prairies Ecozone (Sheffield et al. 2014) have. The bee fauna of Nova Scotia was also the first to be subjected to an extensive DNA barcoding effort (Sheffield et al. 2009), starting in the early 2000s with ongoing diversity assessments (i.e., Sheffield et al. 2003, 2008).

Bee identification is well known to be challenging for several speciose genera in North America (see Packer et al. 2009a; Droege et al. 2010;
Gibbs 2010) due to lack of keys and taxonomic expertise for some taxa. Historically, even the greatest bee taxonomists of their time had trouble distinguishing species - T.D.A. Cockerell (1866-1948) described more bee species than any other person (with 3132 still considered valid today; Ascher and Pickering 2017), but in several cases he (alone or as a coauthor) described the same species multiple times (sometimes in a single manuscript) that today are considered one. Early taxonomists (and likely many today) had limited ability to accurately link specimens to geography, associate sexes, etc., so often described specimens with slight variations in size and/or colour as new species or subspecies (or varieties). Allometric variation among castes in some eusocial Halictidae species (Gibbs 2010), or linked to body size in Ceratina Latreille (Apidae) (Rehan and Sheffield 2011), has also likely contributed to the taxonomic difficulties observed in some bee taxa. Since then, taxonomists have seen the advent of high resolution microscopes, computers and extensive collection databases (e.g., Meier and Dikow 2004), wide and mostly free availability of taxonomic literature and other taxonomic resources (e.g., Biodiversity Heritage Library, university journal databases), and easier exchange of material for study within and among countries, including data sharing (including actual specimens and/or high-quality photographs, and specimen data). Incorporation of high-quality images into web-based interactive taxonomic keys (e.g., the mandate of the Canadian Journal of Arthropod Identification) has also facilitated accurate species level identification for the taxa that have received treatment. Despite these tools, many Canadian bee taxa are in need of revision. The challenge for today's generation of taxonomists will be overcoming challenges to train the next generation of taxonomists to understand the range of software and procedures to construct and test phylogenies (morphological and molecular), species concepts, predictive models for distribution, and find employment to do so as a career. Ongoing work on bee taxonomy in Canada (primarily at York University, Toronto, Ontario, Canada) will be aided by the recent (since 2009) hiring of three additional full-time bee systematists in collection-based institutions (Royal Saskatchewan Museum, University of Manitoba, Canadian National Collection of Insects, 
Arachnids, and Nematodes), which has already resulted in a number of published works on the taxonomy of Canadian bees (Gibbs 2010; Rehan and Sheffield 2011; Sheffield et al. 2011b; Dumesh and Sheffield 2012; Onuferko 2017).

One important change in taxonomic research since the inception of the Biological Survey of Canada 40 years ago has been the development of molecular taxonomy tools. Genetic-based identification systems such as DNA barcoding (as per Hebert et al. 2003a, 2003b) have emerged as powerful and cost-effective tools for accurate identification of biota and assessing and understanding the extent of diversity in groups that have proven difficult using classical taxonomic techniques (Köhler 2007; Packer et al. 2009a). For North America, and Canada in particular, several DNA barcoding projects have been undertaken for pollinators (e.g., Sheffield et al. 2009; Hebert and Landry 2010; Hebert and Humble 2011; Zahiri et al. 2014, 2017), and many other taxa. These DNA barcode libraries can assist traditional morphological taxonomy by allowing identification of life stages for which keys are not available and/or taxonomy is more difficult (e.g., Slowik and Blagoev 2012), associating sexes (e.g., Sheffield et al. 2011b), and in studies assessing biological diversity within regional (e.g., Sheffield et al. 2009) and poorly studied habitatspecific biotas (e.g., Smith et al. 2005, 2009; Stahlhut et al. 2013). DNA barcode sequences (i.e., cytochrome $c$ oxidase subunit I (COI)) and other genetic sequences themselves also contribute to molecular systematics; combining the DNA barcode gene with a single nuclear gene has proven useful for accurate, node-dated phylogenies for bees (Trunz et al. 2016). Ultimately, these efforts to increase taxonomic knowledge can inform conservation efforts (Soltis and Gitzendanner 1999; Hajibabaei et al. 2007; Goldstein and DeSalle 2011). Important caveats to relying on DNA methods are that reference material (i.e., identified specimens that have been sequenced) must be accurately identified (Collins and Cruickshank 2013), and that species do not show high levels of intraspecific variation (e.g., Spooner 2009).

The primary objective of this study is to summarise our efforts to date in developing a "Bees of Canada" DNA barcode database to facilitate taxonomic and faunal studies of bees in Canada.
This effort builds on previous DNA-facilitated taxonomic revisions (e.g., Gibbs 2010; Sheffield et al. 2011b) and regional data sets (e.g., Sheffield et al. 2003, 2009) for Canada, and other regional faunas or taxonomic treatments outside of North America (Carolan et al. 2012; Magnacca and Brown 2012; Francoso and Arias 2013; Schmidt et al. 2015). Specifically, we will determine how well the accumulated number of unique barcode index numbers, which show high concordance with species (Ratnasingham and Hebert 2013) for sequenced Canadian bees, matches our numerical species tally and the known composition of species from Canada. Barcode index number assignment can be used to verify species identifications as well as document diversity when taxonomic information is lacking (Ratnasingham and Hebert 2013). Comparisons will be done nationally, provincially/territorially for species, and at the genus level. We also highlight how DNA barcoding is contributing to bee faunistic knowledge and traditional taxonomic work in Canada, and provide examples of how DNA barcodes can be, and have been, used to complement morphological methods to increase our taxonomic knowledge, including in phylogenetic studies, and discuss the issues and limitations with the current status of Canadian bee taxonomic knowledge. Thus, the diversity and taxonomy of bees in Canada provides a good illustration of the advances in biodiversity study that have occurred during the time period covered by the Biological Survey of Canada, and will complement the bees of Canada image library (www.yorku.ca/bugsrus/ resources/galleries/boc), a checklist of the bees of Canada (in preparation) and a soon to be launched "Bees of Canada" website (www.beesofcanada. com). In addition to a full catalogue treatment, the latter will provide images, distributional information (i.e., jurisdiction, ecozone), floral hosts, and literature for all bee species occurring in Canada.

\section{Methods}

\section{Material for DNA barcoding}

The development of a DNA barcode library for bees began at a regional level (i.e., Nova Scotia) in the early 2000s, with a summary publication in 2009 (Sheffield et al. 2009). Since the onset of the campaign to barcode Canada's bees in 2006 - a 
component of a larger effort to barcode the world's bees (Packer et al. 2008, 2009b) - samples have been collected from across North America, with special focus within southern Canada (Fig. 1). These have been combined with museum specimens from the following Canadian and United States of America collections: Packer Collection at York University; Biodiversity Institute of Ontario, University of Guelph (Guelph, Ontario, Canada); J.B. Wallis-R.E. Roughley Museum of Entomology, University of Manitoba (Winnipeg, Manitoba, Canada); Royal Saskatchewan Museum (Regina, Saskatchewan, Canada); Royal British Columbia Museum (Victoria, British Columbia, Canada); Simon Fraser University (Vancouver, British Columbia, Canada); Canadian National Collection of Insects, Arachnids, and Nematodes (Ottawa, Ontario, Canada); American Museum of Natural History (New York, New York, United States of America); Smithsonian National Museum of Natural History (Washington, District of Columbia, United States of America); United States Department of Agriculture, Agricultural Research Service Bee Biology and Systematics Laboratory (Logan, Utah, United States of America); United States Geological Survey Patuxent Wildlife Research Center (Laurel, Maryland, United States of America); and other contributors. The majority of DNA barcoded specimens from Canada are deposited at York University and the Biodiversity Institute of Ontario.

\section{Tissue sampling and molecular protocols}

For barcoding bees, tissue samples (i.e., usually a single mesothoracic or metathoracic leg from pinned specimens) were removed and sent to the Biodiversity Institute of Ontario for extraction and sequencing using well-established protocols (e.g., Hajibabaei et al. 2005). Barcode index numbers are assigned to sequences in the Barcode of Life Datasystems (Ratnasingham and Hebert 2007) using a sequential process of algorithms using predefined distance thresholds with refined clustering of sequences, each of which represents an algorithmically grouped barcode sequence or group of sequences, with constituents of each barcode index number usually showing a high concordance within species boundaries (Ratnasingham and Hebert 2013). To summarise the DNA barcodes of the bee fauna of Canada as a whole, single representatives of each species/barcode index number, regardless of how many taxon names were associated with that barcode index number, were selected for analysis from the thousands of specimens that are currently barcoded. This differed from studies looking at intraspecific sequence divergence (which use multiple individuals of each species from multiple locations; Bergsten et al. 2012). Among this material, sequence data were downloaded from the barcode of life data system and imported in Mega Version 7 (Kumar et al. 2016) for sequence alignment and construction of an neighbour-joining tree using the neighbourjoining algorithm with the K2P model, with pairwise deletion of missing data, and the inclusion of all codon positions and substitution types (as used in the barcode of life data system analytical module). The patterns were then visualised using FigTree v1.4.2 (http://tree.bio.ed.ac.uk/ software/figtree/).

A checklist of known Canadian bee species, including those in each province and territory was prepared for a national conservation assessment (Canadian Endangered Species Conservation Council 2016). This species checklist formed the basis for assessing completion of the DNA barcoding campaign for Canada. Genus-level summaries of the number of valid species known to occur in Canada, and comparable number of unique barcode index numbers were prepared. As the species data and barcode index numbers were also partitioned by jurisdiction (i.e., province and territory), tallies of barcode index numbers represented in each province (and associated with taxonomic information) were compared with these data to show diversity of both known species and barcode index numbers per jurisdiction. This included specimens within a single barcode index number, which had no species-level identification. Only one representative of each barcode index number was added to the tally, regardless of the species-level identification associated with the DNA barcoded specimens, as the comparisons were of known species to barcode index numbers within each genus.

\section{Results and discussion}

Much of the sampling to date has been focussed in areas of southern Canada (south of $50^{\circ} \mathrm{N}$ ) (Fig. 1), but this region supports almost all of the species known from Canada (see Sheffield et al. 2014), 
Fig. 1. Bee barcode sampling intensity in Canada. Darker coloured squares represent areas with more intensive sampling.

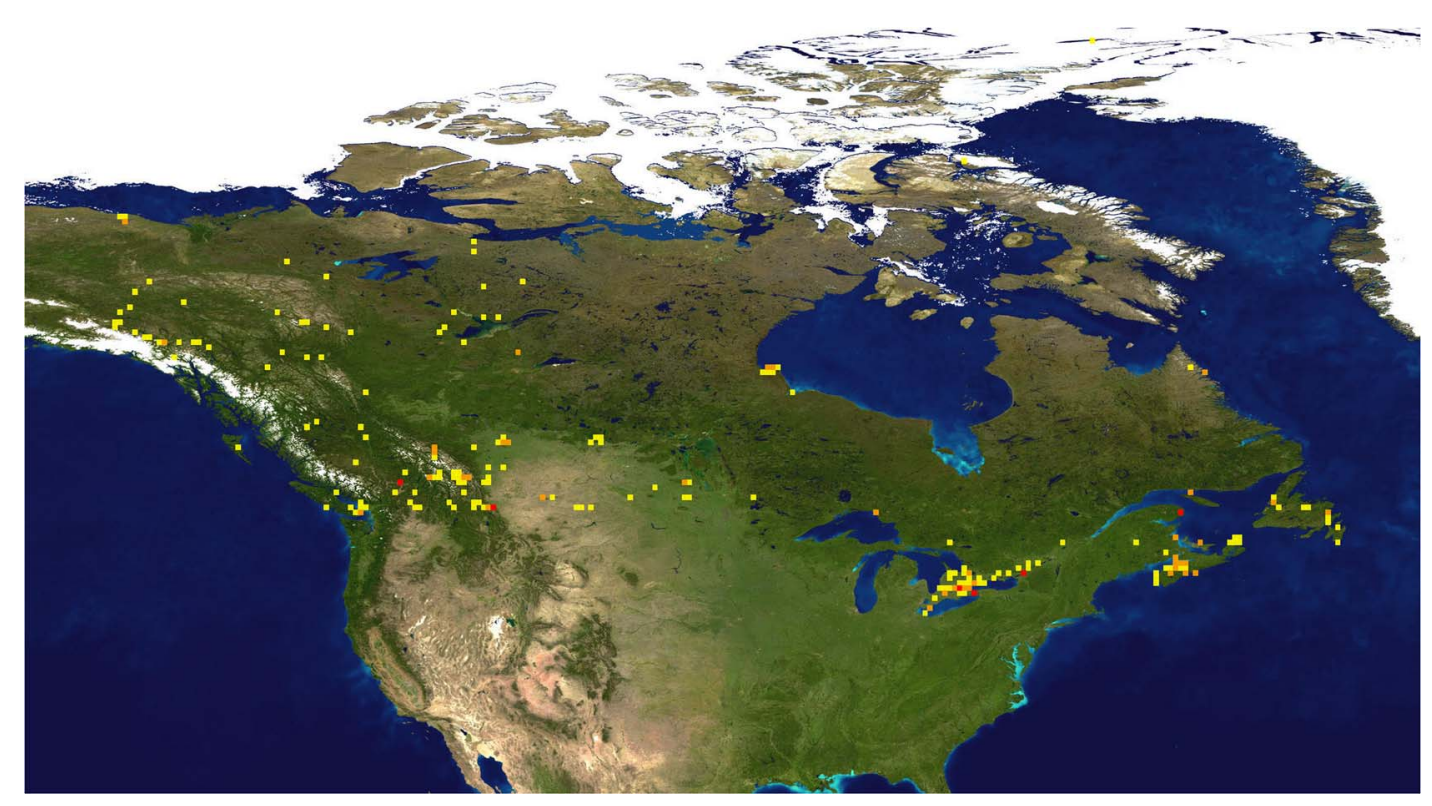

suggesting that the specimens received are largely representative of bee diversity in Canada. Approximately 14200 bee specimens have been processed for DNA barcoding, and these have yielded 12600 barcode-compliant sequences, resulting in 811 distinct barcode index numbers from within Canada (Fig. 2). This value represents $95 \%$ of the total of 856 species presently known from Canada (Table 1), but comparison of barcode index numbers with known species patterns in different genera shows that many more species may be present. It is likely that the actual number of species, and barcode index numbers assigned to these species, will continue to increase with continued sampling.

Of the 52 genera currently recorded in Canada, only $25(45 \%)$ have all known species barcoded, though most of these are represented by less than five species (Table 1, Figs. 3-4). In most (20) of the remaining genera, fewer barcode index numbers have been recorded than the known morphological species suggesting that these taxa have not been fully sampled. Some of these discrepancies are due to multiple morphologically distinct species sharing a barcode index number (e.g., Lasioglossum Curtis (Halictidae); see full discussion under Issue 2, below). By contrast, other genera have more barcode index numbers recorded for them than the known species in Canada (Table 1, Figs. 3, 4) even though two of these (Megachile Latreille (Megachilidae), Bombus Latreille (Apidae)) have had recent taxonomic treatment (Sheffield et al. 2011b; Williams et al. 2014, respectively). The remaining genera in this category are among those needing the most taxonomic work, and are largely responsible for the differences in the number of species and barcode index numbers observed in many parts of Canada (Fig. 5), especially British Columbia, the Prairie Provinces, and Ontario.

At the species level, of the 856 species recorded from Canada, 253 have no clearly associated barcode index number due to lack of material, poor success in obtaining sequences, or taxonomic uncertainty in assigning a name to the specimen associated with a sequence. An additional 28 species share barcode index numbers with other taxa, so the number of barcode index numbers cannot equal the number of species. On the other hand, 237 barcode index numbers are not currently associated to specific taxa (four of these represent cases where subspecific differences in barcode index numbers are observed). 
Fig. 2. Neighbour-joining (NJ) tree for single representative COI barcode sequences (BINs) for the bees of Canada. Colours represent the six bee families in Canada. Note that in this $\mathrm{NJ}$ tree, the families Andrenidae and Colletidae appear multiple times.

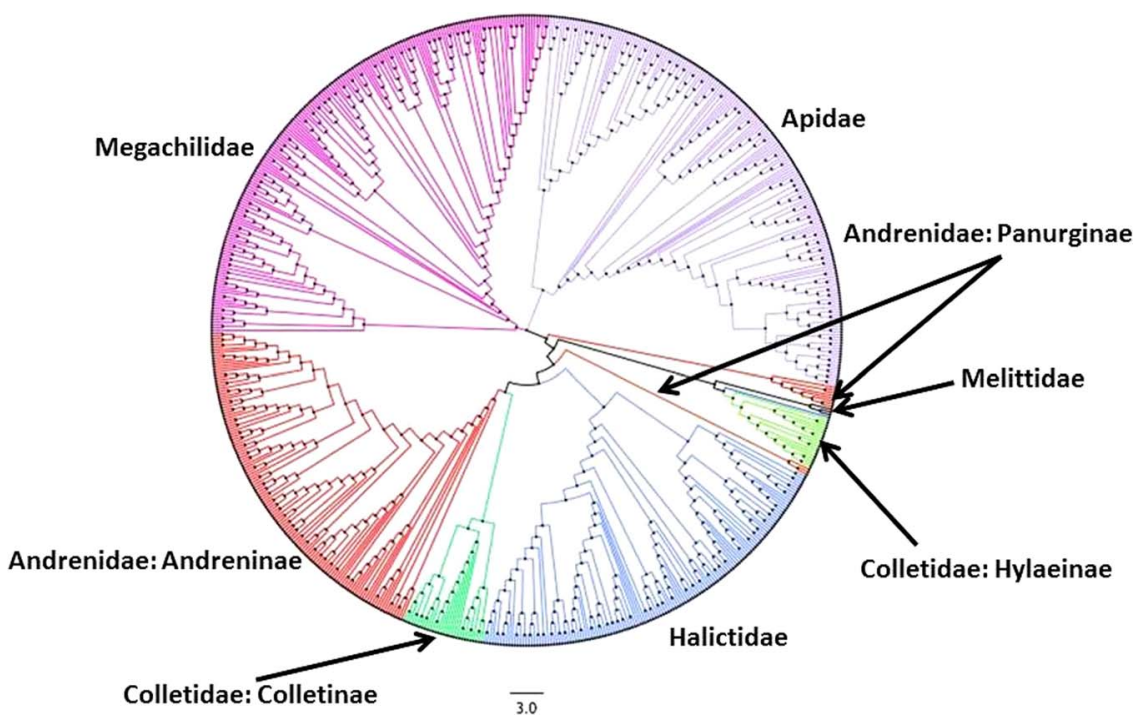

The combined use of species and barcode index numbers alters our understanding of bee diversity in Canada, both nationally and at the provincial/territory level (Fig. 5). This is particularly true in British Columbia where the actual diversity of bees may fall between 500 and 600 species. These data suggest that there is still much taxonomic work to be done on Canadian bees, particularly within the genera Hylaeus Fabricius (Colletidae), Nomada Scopoli (Apidae), Sphecodes Latreille (Halictidae), and Osmia Panzer (Megachilidae), though a solid framework supporting taxonomic studies has been built in the barcode of life data system.

One issue to be resolved will be to ensure that all specimens sharing barcode index numbers are examined using traditional morphological taxonomic methods to support accepted taxonomy and nomenclature. Though specimens used to populate the bees of Canada DNA barcode project in barcode of life data system should be identified before being added (e.g., Collins and Cruickshank 2013), some speciose taxa are lacking keys and/or taxonomic specialists (and may have high numbers of undescribed species), making a priori identifications unlikely. Another consideration is the fact that many bee species are sexually dimorphic, and one of the sexes for many of these may be unknown or not associated (e.g., Sheffield and Westby 2007), leading to inaccurate estimates of total species richness. Therefore, accessible DNA-based identification tools can be considered a major innovation in species diversity assessment in the 40 years since the inception of the Biological Survey of Canada. However, even as we should not assume that all taxa can be separated morphologically (e.g., Carman and Packer 1996; Danforth et al. 1998; Packer et al. 2009a), neither can we assume that barcodes alone will address all biodiversity questions (Gibbs 2010). This concept can be illustrated by examining the discrepancies between the known species and the barcode index numbers found in the bees of Canada data set. We summarise these below, provide a genus-by-genus account of where additional taxonomic work is required, and lastly provide examples of how and where combining DNA barcoding and traditional morphological taxonomy has been successful in studies of Canadian bees.

\section{What are the issues?}

Issue 1. One species: multiple barcode index numbers. Collins and Cruickshank (2013) note that it is desirable to populate barcode of life data system with a priori identified specimens to build taxon-specific projects, though multiple 
Table 1. Summary of the bee species in Canada with the number of species known and barcoded from each genus.

\begin{tabular}{|c|c|c|c|c|}
\hline$\underline{\text { Family }}$ & Genus & Species recorded & Barcode index numbers & Difference \\
\hline \multirow[t]{2}{*}{ Colletidae } & Colletes & 34 [+4 ssp] & 26 & $-8[-12]$ \\
\hline & Hylaeus & $20[+1 \mathrm{ssp}]$ & 30 & $+10[+9]$ \\
\hline \multirow[t]{5}{*}{ Andrenidae } & Andrena & $149[+1 \mathrm{ssp}]$ & 132 & $-17[-18]$ \\
\hline & Calliopsis & 5 & 5 & $*$ \\
\hline & Panurginus & 4 & 3 & -1 \\
\hline & Perdita & $12[+1 \mathrm{ssp}]$ & 10 & $-2[-3]$ \\
\hline & Pseudopanurgus & 12 & 6 & -6 \\
\hline \multirow[t]{9}{*}{ Halictidae } & Agapostemon & 7 & 7 & \\
\hline & Augochlora & 1 & 1 & \\
\hline & Augochlorella & 1 & 2 & \\
\hline & Augochloropsis & 1 & 1 & \\
\hline & Dieunomia & 1 & 1 & \\
\hline & Dufourea & 8 & 8 & \\
\hline & Halictus & 7 & 11 & +4 \\
\hline & Lasioglossum & 141 & 115 & -26 \\
\hline & Sphecodes & 33 & 51 & +18 \\
\hline \multirow[t]{2}{*}{ Melitidae } & Macropis & 2 & 1 & -1 \\
\hline & Melitta & 1 & 1 & \\
\hline \multirow[t]{13}{*}{ Megachilidae } & Anthidiellum & 2 & 2 & \\
\hline & Anthidium & 11 & 8 & -3 \\
\hline & Ashmeadiella & 4 [+1 ssp] & 4 & {$[-1 ?]$} \\
\hline & Atoposmia & 2 & 2 & \\
\hline & Chelostoma & 5 & 5 & \\
\hline & Coelioxys & 21 & 20 & -1 \\
\hline & Dianthidium & 7 & 6 & -1 \\
\hline & Dioxys & 1 & 1 & \\
\hline & Heriades & 4 & 4 & \\
\hline & Hoplitis & $12[+3 \mathrm{ssp}]$ & 12 & {$[-3]$} \\
\hline & Megachile & $40[+1 \mathrm{ssp}]$ & 43 & $+3[+2]$ \\
\hline & Osmia & $79[+1 \mathrm{ssp}]$ & 87 & $+8[+9]$ \\
\hline & Stelis & 21 & 6 & -15 \\
\hline \multirow[t]{21}{*}{ Apidae } & Anthophora & 12 & 12 & * \\
\hline & Apis & 1 & 1 & \\
\hline & Bombus & 44 [+2 ssp] & 51 & $+7[+5]$ \\
\hline & Ceratina & 8 & 5 & -3 \\
\hline & Diadasia & 3 & 4 & +1 \\
\hline & Epeoloides & 1 & 1 & \\
\hline & Epeolus & 12 & 12 & $*$ \\
\hline & Eucera & 11 & 2 & -9 \\
\hline & Habropoda & 2 & 1 & -1 \\
\hline & Holcopasites & 5 & 3 & -2 \\
\hline & Melecta & 3 & 3 & \\
\hline & Melissodes & 27 [+1 ssp] & 18 & $-9[-8]$ \\
\hline & Neolarra & 2 & 1 & -1 \\
\hline & Neopasites & 1 & 1 & \\
\hline & Nomada & 55 & 81 & +26 \\
\hline & Peponapis & 1 & 1 & \\
\hline & Svastra & 1 & 1 & \\
\hline & Triepeolus & 20 & 12 & -8 \\
\hline & Xeromelecta & 1 & 1 & \\
\hline & Хуlосора & 1 & 1 & \\
\hline & Zacosmia & 1 & 1 & \\
\hline
\end{tabular}

"ssp" = multiple subspecies are recognised in Canada. See generic treatment for genera with a "+", “_", or "*” in the last column; values in [] represent the difference when subspecies are considered. 
Fig. 3. Summary of the proportion of bee species for each genus for which there are barcodes with assigned barcode index numbers. Genera represented by bars less than 1.00 have more species recorded than barcode index numbers; greater than 1 have more barcode index numbers than species recorded in Canada.

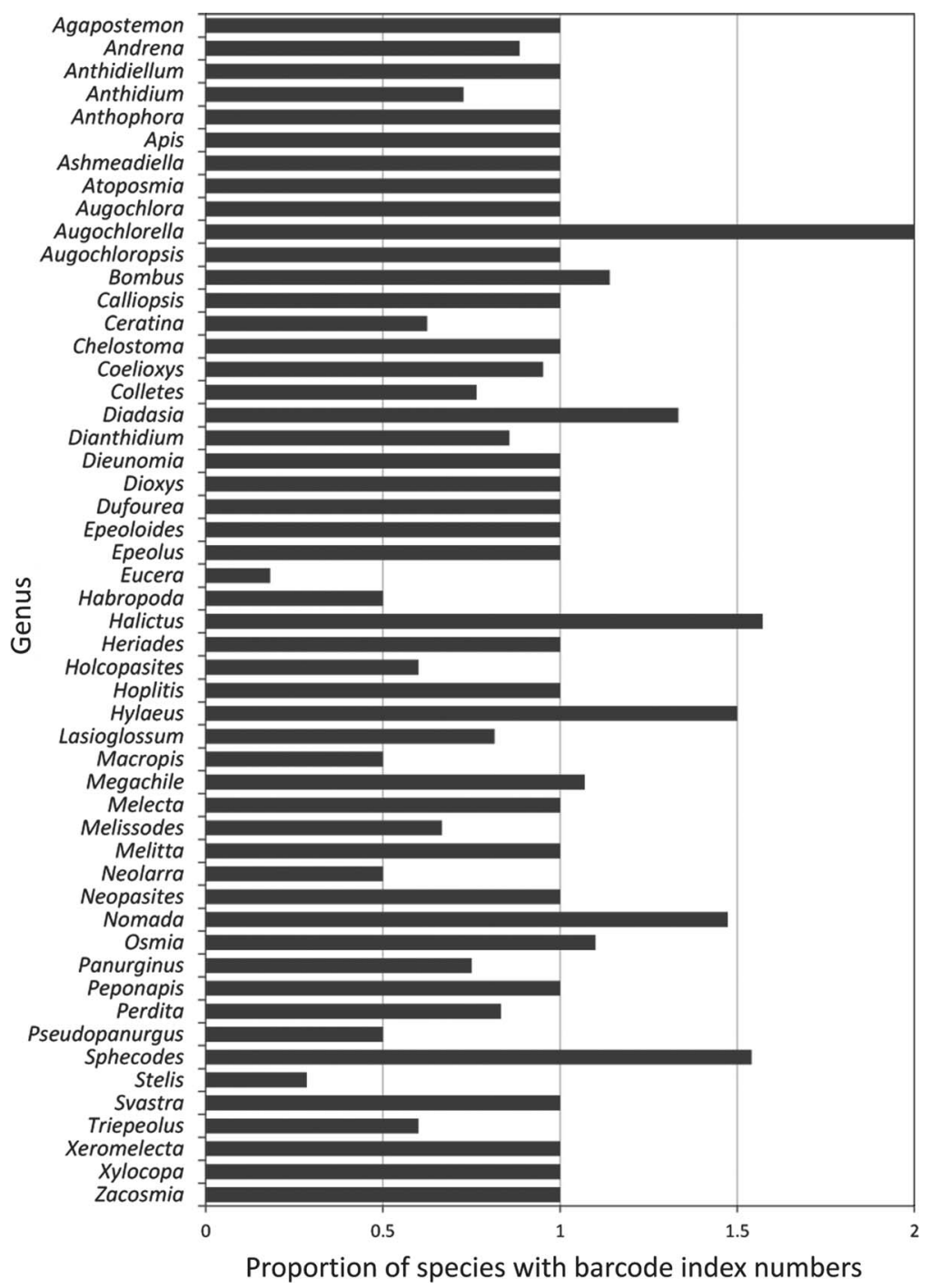

barcode index numbers and/or high levels of sequence variation can be recognised after the fact. There are a few cases in which bee specimens recognised as good morphologically identified species have multiple barcode index numbers. For instance, among the well-studied bumble bees (Apidae: Apinae: Bombini), Bombus impatiens Cresson and B. ternarius Say each have three barcode index numbers represented by Canadian material in barcode of life data system. The fact that the representatives of each barcode index number cluster together suggests that this is not the result of misidentification but rather slight, but consistent variation in COI, without any pattern associated with morphology or geography.

Other discrepancies are likely due to cryptic species within poorly studied groups, or groups needing further study (see Discussions below). Another possibility is heteroplasmy, in which a single specimen can yield two different DNA barcodes (and possibly barcode index numbers), 
Fig. 4. The number of species (white bars) and number of barcode index numbers (black bars) for each genus of bee within Canada; $x$-axis $\log ^{10}$ scale.

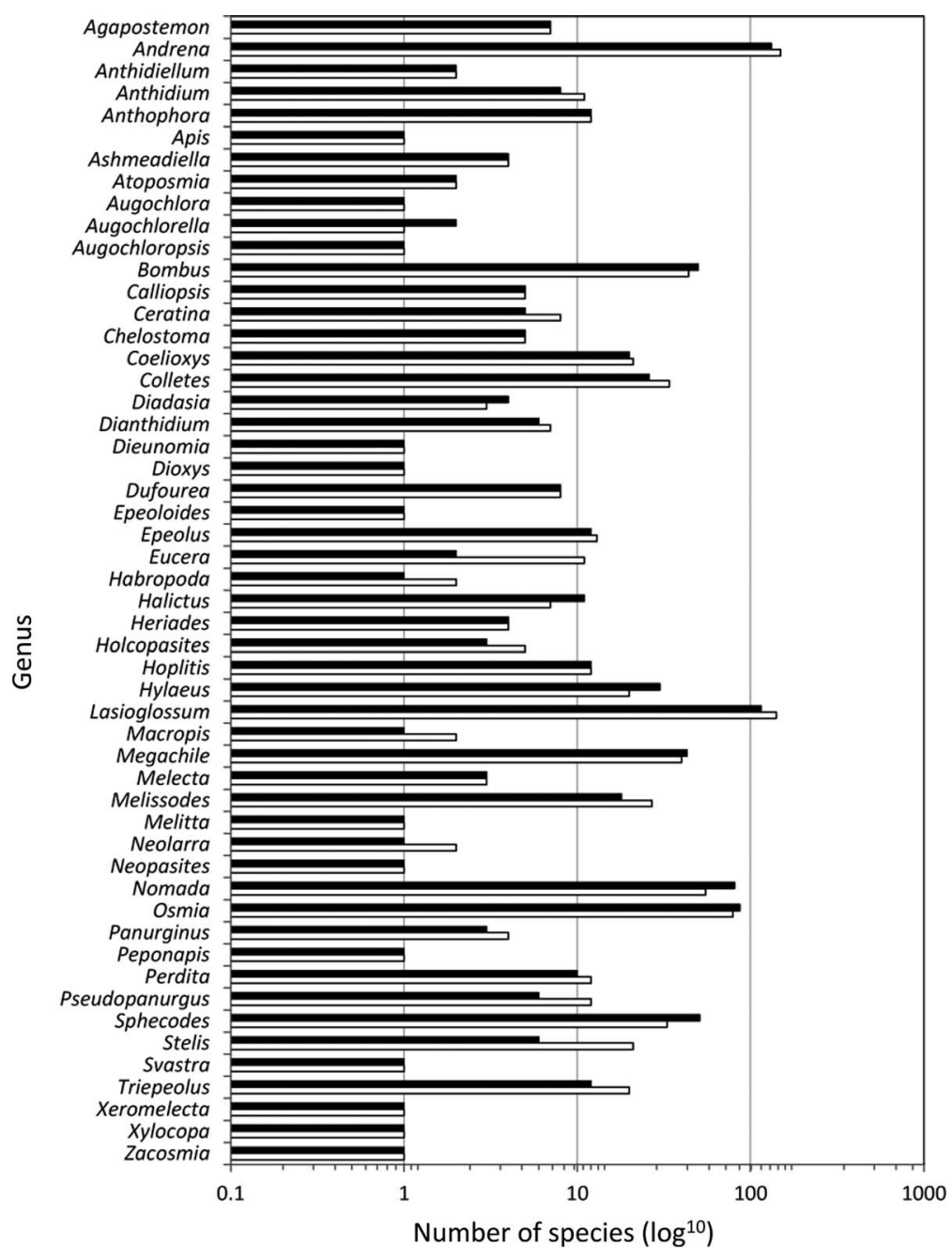

as reported for the genus Hylaeus by Magnacca and Brown (2009, 2010), though this may largely go undetected as usually only a single tissue sample (e.g., a leg) is used for each specimen. Currently, studies have begun to address these types of patterns within the genus Hylaeus in Canada. At least three species, Hylaeus coloradensis (Cockerell), H. mesillae (Cockerell), and $H$. modestus Say show multiple barcode index numbers, though this group is rather difficult taxonomically, and much morphological variation within species has resulted in many synonymies. For example, $H$. modestus has two recognised subspecies and eight additional junior synonyms (Hurd 1979). These examples may also illustrate that for widespread species, it is important to sample multiple specimens of each species across its range; Bergsten et al. (2012) suggest that at least 70 individuals from throughout the range (of a wide ranging species) would be required to account for $95 \%$ of the variation within a species. This may be even more important for Holarctic species; Andrena barbilabris (Kirby) (Andrenidae) is an example of a Holarctic species with three barcode index numbers in North America alone. Halictus confusus Smith (Halictidae) is an even 
Fig. 5. The number of recorded bee species (blue bars) and barcode index numbers (red bars) for each jurisdiction in Canada. The combined data for both (purple bar) includes species and barcode index numbers, including barcode index numbers not associated with species names, so likely represents an overestimation of total species. YT, Yukon; NT, Northwest Territories; NU, Nunavut; BC, British Columbia; AB, Alberta; SK, Saskatchewan; MB, Manitoba; ON, Ontario; QC, Québec; NB, New Brunswick; NS, Nova Scotia; PE, Prince Edward Island; Lab, Labrador; NL, Newfoundland.

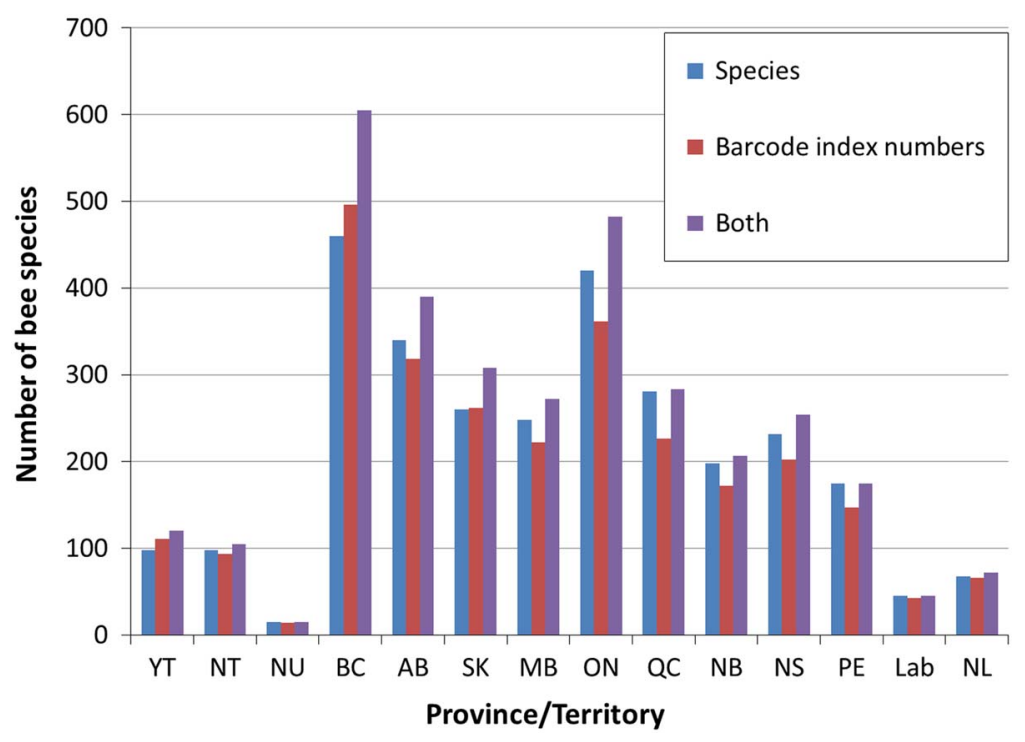

more pronounced example, with five barcode index numbers in North America, though two subspecies are recognised on the continent, which may explain this partially, though Rosenmeier and Packer (1993) found no species-level differences among H. confusus populations from Alberta, Ontario, and Nova Scotia using electrophoretic methods for 40 loci. Sheffield and Perron (2014) offered some discussion of the implications for nomenclature for this species. There are other recent examples of Holarctic species being recognised as multiple taxa (e.g., Gibbs et al. 2013), including in the genus Bombus subgenus Alpinobombus Skorikov, in which multiple Holarctic species were recognised as separate Old and New World taxa (Williams et al. 2015); Williams et al. (2016) later described one of these as a new species, B. kluanensis Williams and Cannings.

Issue 2. Multiple species: one barcode index number. In contrast to species with multiple barcode index numbers discussed above, there are also several cases in this data set in which multiple species share a single barcode index numbers. Examples are found in the genera Ceratina,
Lasioglossum, and Bombus. Rehan and Sheffield (2011) recently described a new species of Ceratina (subgenus Zadontomerus Ashmead) in eastern North America, one of four species sharing a single barcode index numbers. However, phylogenetic analysis of the COI data combined with morphological (Rehan and Sheffield 2011) and ecological data (Vickruck et al. 2011) supported the recognition of all four species as valid. Similarly, some clearly recognised species of bumble bees share barcode index numbers, though additional molecular analysis has facilitated the recognition of valid Nearctic/Palaearctic forms (Williams et al. 2015) and new species (Williams et al. 2016). In other cases (discussed below), incidences of multiple species sharing barcode index numbers have resulted in synonymies, largely supporting that many bumble bees are colour variable (Williams et al. 2014). Lastly, there are many species of Lasioglossum subgenus Dialictus Robertson that share a barcode index number. In one example, at least 16 species share one barcode index number and would not be readily separated by DNA barcoding alone (i.e., use of barcode index numbers), 
though they can be separated by morphology and geography (Gibbs 2010).

Issue 3. Multiple specimens, no barcode index numbers. Despite our attempts to obtain full DNA barcodes, a number of species have not yielded fully compliant sequences with barcode index numbers assigned. These include Andrena carlini Cockerell, Calliopsis chlorops Cockerell, Lasioglossum athabascense (Sandhouse), L. coeruleum (Robertson), L. colatum (Vachal), L. pallidellum Ellis, and $L$. reasbeckae Gibbs. Similar issues were found for some species in other bee-barcode campaigns, often associated with the presence and coamplification of the bacterial endosymbiont Wolbachia Hertig (Rickettsiaceae) (Magnacca and Brown 2012; Schmidt et al. 2015).

Some Canadian species are very rare, some known only from type material collected decades previously (e.g., holotype and two paratypes of Andrena fulgida LaBerge), so it is likely that a DNA barcode library will never be complete unless these species are deemed synonymies of other taxa. It is important to note that there has been success in getting sequences from old material (Hajibabaei et al. 2006; Shokralla et al. 2011), though this is also influenced by methods used to collect and/or store specimens (Sheffield et al. 2009). The willingness of institutions to have historic and rare type material subject to tissue removal for DNA barcoding is also likely an issue. Further, the rarity and/or taxonomic ambiguity of some of these species increases the probability that they will not be routinely sampled. As discussed by Lim et al. (2012), the sampling effort required to obtain some rare species is enormous.

Despite some of the difficulties mentioned above, many of which should be resolved with further molecular work and analyses (e.g., Dowton et al. 2014; Williams et al. 2015, 2016) and increased sampling (Bergsten et al. 2012), the value of DNA barcoding to support traditional taxonomic work has been illustrated in several works (see above and Collins and Cruickshank 2014). Analysis of the Canadian bee fauna provides a good example of this for some groups, and also illustrates where more taxonomic work needs to be done. We discuss the genera with discrepancies between the number of species and the number of barcode index numbers below (arranged by family and alphabetically by genus within each family) (Table 1).

\section{Family Colletidae}

Colletes Latreille. At present, 34 species are known from Canada, four of these with recognised subspecies. Specimens have not been collected and/or COI sequences have not yet been obtained for eight of these. However, Colletes kincaidii Cockerell is represented by two unique, yet closely associated barcode index numbers.

Hylaeus Fabricius. There are 30 unique barcode index numbers recorded from Canada, potentially representing ten more species than the 20 presently recorded from Canada. The taxonomy and identification of Hylaeus has traditionally been based on the presence and extent of colour markings, and variations within species have resulted in multiple junior synonyms for some (e.g., H. mesillae). In other species (e.g., $H$. affinis (Smith), H. modestus), females are very difficult to reliably distinguish. Members of this genus are also easily introduced outside of their native range, with several non-native species now established in North America, with many recent arrivals (Sheffield et al. 2011a; Gibbs and Dathe 2017; Martins et al. 2017). Thus, undocumented non-native species are also a possibility. Magnacca and Brown $(2009,2010)$ indicated that heteroplasmy within some Hylaeus (species outside of North America) creates some issues for successful specimen identification using DNA barcodes (i.e., potentially multiple barcode index numbers for a single specimen), though it is not presently known if this is an issue within the Canadian fauna as typically only a single tissue sample is used for each specimen.

\section{Family Andrenidae}

Andrena Fabricius. There are likely many more Andrena species yet to be recorded in Canada, in addition to the 149 species confirmed, 132 barcode index numbers have been recorded, 19 of which have not yet been examined for identification to species level. Several species have multiple barcode index numbers, including Andrena barbilabris (a Holarctic species represented by three barcode index numbers in North America alone). Andrena still requires much attention, as many misidentifications within 
barcode of life data system have resulted in multiple names associated with barcode index numbers.

Calliopsis Smith. Five species and five barcode index numbers have been recorded from Canada, though two of the barcode index numbers are from a single species, Calliopsis andreniformis Smith. Calliopsis chlorops has not yet been successfully barcoded, despite numerous attempts.

Panurginus Nylander. Four species are known from Canada, and only two have been barcoded with barcode index numbers. One species, $P$. ineptus Cockerell has two barcode index numbers. An additional specimen with a non-barcodecompliant sequence may represent a fifth species.

Perdita Smith. A total of 12 species have been recorded from Canada, with one represented by two subspecies. There are 10 barcode index numbers, two of these not yet associated with a named species.

Pseudopanurgus Cockerell. Of the 12 species recorded from Canada, two have associated barcode index numbers, with five additional barcode index numbers not yet assigned to a species.

\section{Family Halictidae}

Augochlorella Sandhouse. Coelho (2004) synonymised A. striata (Provancher) under A. aurata (Smith) resulting in one species recorded from Canada, but there are two barcode index numbers. Ordway (1966) originally suggested much morphological variation in A. striata, so it is likely that more detailed analysis of morphology and barcoding is required.

Halictus Latreille. At present, seven species are known from Canada, represented by 11 barcode index numbers. As discussed above, the Holarctic species $H$. confusus is responsible for much of the discrepancy (four barcode index numbers) (also see discussion in Sheffield and Perron (2014)), with $H$. tripartitus Cockerell accounting for two barcode index numbers.

Lasioglossum Curtis. The genus Lasioglossum has 141 known Canadian species and is represented by 115 barcode index numbers. Many of the species currently recognised morphologically (see Gibbs 2010) share barcode index numbers and account for much of the discrepancy between barcode index numbers and species, with most of the remaining discrepancy due to the number of species not yet barcoded. There are cases, such as L. cressonii (Robertson) and L. ruidosense (Cockerell), where morphologically and geographically defined species have multiple barcode index numbers (Gibbs 2010). The recent works of Gibbs (2009, 2010, 2011) and Gibbs et al. (2013) are examples of the benefit of including DNA barcodes as part of revisionary taxonomy to resolve issues in difficult bee taxa.

Sphecodes Latreille. Sphecodes is one of the genera in Canada in most need of revision. At present, 33 species have been recorded from Canada, though there are 51 barcode index numbers. Currently, no key to species exists for western North America, and that for the east (Mitchell 1960) is not representative of all the species in the area.

\section{Family Melittidae}

Macropis Panzer. Two species occur in Canada, both oligoleges of Lysimachia Linnaeus (Primulaceae) flowers, though one (M. ciliata Patton) is very rare, and no material has been barcoded.

\section{Family Megachilidae}

Anthidium Fabricius. At present, 11 species of Anthidium (three are non-native), are known from Canada, and eight of these have barcode index numbers.

Ashmeadiella Cockerell. There are four species recorded from Canada, one with two subspecies, and four barcode index numbers. It is likely that the DNA barcodes do not differ in the two subspecies.

Coelioxys Latreille. There are 21 species confirmed from Canada, and 20 barcode index numbers, though two species have no barcode index numbers associated with them, and two other species have multiple barcode index numbers. There may be misidentifications in barcode of life data system, but this group needs revision.

Dianthidium Cockerell. There are seven species recorded from Canada, and six barcode index numbers; two species (D. curvatum (Smith) from British Columbia, and D. simile (Cresson) from Ontario) share a barcode index number.

Hoplitis Klug. For the 12 species recorded in Canada, there are 12 barcode index numbers, but one species has not yet been barcoded. Though two species occurring in Canada have subspecies, 
no variation in barcodes is apparent within these species. Two taxa have multiple barcode index numbers.

Megachile Latreille. Since Sheffield et al. (2011b) revised the 38 species in Canada, Bzdyk (2012) and Sheffield and Genaro (2013) raised two subspecies to species (M. snowi Mitchell and M. cleomis Cockerell, respectively), resulting in 40 species in Canada. In all, 43 barcode index numbers have been recorded, but one species, M. umatillensis (Mitchell) has no barcode index number associated with it, M. gemula Cresson and $M$. relativa Cresson each have two, and M. pugnata Say has three (supporting subspecies).

Osmia Panzer. Due to the species richness of this genus, and the difficulty in identifying species, Osmia is one of the genera most in need of revision. Currently, there are 79 species recorded from Canada, and 87 barcode index numbers. Only 66 species have associated barcode index numbers, and there are 21 barcode index numbers not yet assigned to specific taxa and/or representing multiple barcode index numbers of a single named taxon. Likely many of these are the result of misidentification.

Stelis Panzer. These cleptoparasites are in need of revision, with 21 species recorded from Canada but only six with associated barcode index numbers.

\section{Family Apidae}

Anthophora Latreille. There are 12 species recorded from Canada, and 12 barcode index numbers, though three species are without barcode index numbers, and three have two barcode index numbers each. One from the latter group likely represents a misidentification.

Bombus Latreille. There are 44 bumble bee species recorded from Canada, including one new species described (Williams et al. 2016) since the last taxonomic treatment of the genus (Williams et al. 2014). The 51 barcode index numbers from Canada include some species with multiple barcode index numbers (see B. impatiens and B. ternarius discussion above), species with recognised subspecies (B. bifarius Cresson and B. occidentalis Greene), and two others currently undergoing further taxonomic study.

Ceratina Latreille. Eight species of Ceratina are known from Canada, represented by five barcode index numbers. The shared barcode index number of four eastern species of Ceratina (Zadontomerus) is discussed above.

Diadasia Patton. The three species in Canada are represented by four barcode index numbers. One species, Diadasia australis (Cresson), is represented by two closely associated barcode index numbers, one on the eastern side of the Rockies, one on the west.

Epeolus Latreille. There are 12 unique barcode index numbers for the 12 species recorded from Canada, although a 13th species (yet to be barcoded) has been also been recorded in the country (Romankova 2004). The Canadian species of Epeolus were recently revised by Onuferko (2017).

Eucera Scopoli. Of the 11 species thought to be in Canada, only six have been barcoded and have yielded barcode index numbers. It is therefore likely that some species of Eucera are rare in Canada, but material in the barcode of life data system identified as five different species share a single barcode index number. This genus requires revision.

Habropoda Smith. Only one of the two species known from Canada, Habropoda cineraria (Smith), has been barcoded.

Holcopasites Ashmead. Five species are known from Canada, and three of these have barcode index numbers.

Melissodes Latreille. Melissodes is one of the taxa in need of attention; there are 27 species reported from Canada (one with two subspecies), and 18 barcode index numbers, though six of these are not yet associated with valid species.

Neolarra Ashmead. Only one of the two species known from Canada, Neolarra vigilans (Cockerell) has been barcoded.

Nomada Scopoli. Nomada is one of the most taxonomically difficult groups of bees in North America, with few recent keys, and many species known from one sex. This genus is perhaps most in need of taxonomic revision. There are 81 barcode index numbers in barcode of life data system from Canada, representing 55 known species. Only 15 species have been associated with barcode index numbers (and some of these are likely misidentified), and 66 barcode index numbers are without names.

Triepeolus Robertson. There are 20 species recorded from Canada, represented by 12 barcode index numbers, two of these not associated with a species name. 


\section{Future prospects for DNA barcoding and bee taxonomic studies}

\section{Associating sexes}

Among the bees, many speciose genera have high proportions of species known from one sex; Sheffield and Westby (2007) indicated that 37\% of North American leafcutter bees were known from one sex. In a recent revision of the genus Megachile for Canada, Sheffield et al. (2011b) associated the sexes for all 38 species known at that time, resulting in several synonymies. For instance, Megachile alamosana Mitchell, previously known only from the male, was synonymised with Megachile anograe Cockerell, which was known only from the female (Sheffield et al. 2011b) (Fig. 6). In addition, the male of M. sublaurita Mitchell was described for the first time (Sheffield et al. 2011b). Similarly, in the genus Sphecodes, Sheffield et al. (2009) associated Sphecodes carolinus Mitchell to $S$. coronus Mitchell, known from the female and male, respectively. Gibbs (2010) also made 14 sex associations for Lasioglossum (Dialictus) in Canada, in a study that combined both morphological and molecular techniques.

\section{Morphological variation}

In addition to being sexually dimorphic, some bee species also exhibit high morphological variability, especially colour. In bumble bees (genus Bombus) this is particularly common, though for some highly variable species (e.g., B. rufocinctus Cresson), no variation in COI has been reported, nor are there any obvious corresponding geographical patterns associated with these colour variants. In another example, Williams et al. (2014) considered B. californicus Smith a synonym of $B$. fervidus (Fabricius) due to little to no variation in COI (i.e., same barcode index number), though the darker form (i.e., B. californicus) is largely distributed in the west (including British Columbia and Alberta), though with intergrades occurring with the eastern yellow form (B. fervidus). However, despite the molecular evidence and synonymy of Williams et al. (2014), Dolan et al. (2017) still recognised both species in Montana. In another series of studies with bumble bees, Williams et al. (2012) and Sheffield et al. (2016) used geographic patterns of COI to recognise two subspecies of
B. occidentalis, the latter study also including an analysis of geography-based colour variation to help define the distribution of each designatable unit, and assist in the Committee On the Status of Endangered Wildlife In Canada conservation assessment for each (Committee on the Status of Endangered Wildlife in Canada 2014).

\section{Holarctic distribution and introduced species}

Global DNA barcode initiatives, such as BeeBOL (Packer et al. 2008, 2009b) can help detect introduced species and clarify distributions. Introduced bees are commonly detected in Canada (Sheffield et al. 2010, 2011a; Gibbs and Dathe 2017; Martins et al. 2017). More recently, DNA barcoding has helped clarify the distributional status of several bee species, including the confirmation of a Holarctic distribution in Bombus distinguendus Morawitz (Sheffield and Williams 2011), and the recognition of separate Nearctic/Palaearctic distributions of bumble bees of the subgenus Alpinobombus (Williams et al. 2015).

\section{Pollination studies}

In addition to the benefits of incorporating DNA barcoding into traditional bee taxonomic studies, the opportunities for incorporating this technique into bee/pollinator ecological studies are many (Valentini et al. 2009; and see Vamosi et al. 2016 for a discussion related to pollinators and pollination). For instance, the development of techniques for DNA barcoding land plants (e.g., Kress et al. 2005, 2015; Kress and Erickson 2007; Hollingsworth et al. 2011; Li et al. 2015), and bee-collected pollen (e.g., Galimberti et al. 2014) and/or honey (Valentini et al. 2010) allow pollinating bees to be linked to their floral hosts in a range of ecosystems. However, pollen is not the only plant tissue used by bees - recently, MacIvor (2016) demonstrated how DNA barcoding could be used to identify the plant species that leafcutter bees (Megachildae) cut leaf pieces from to build their nests. Lastly, with the development of a DNA barcode library for bees, opportunities for associating cleptoparasitic bees to their host(s) using larvae excavated from nests would provide valuable information on bee communities (e.g., Sheffield et al. 2013). 
Fig. 6. A typical neighbour-joining tree for specimens of Megachile (Megachilidae) species in Canada. In this example, one clade is expanded to illustrate that DNA barcoding revealed that $M$. laurita and $M$. anograe (previously considered valid species known from the female only) were actually just colour variants of the same species. Also illustrated is the association of the male of M. anograe (M. alamosana, also previously considered a valid species). See Sheffield et al. (2011a).

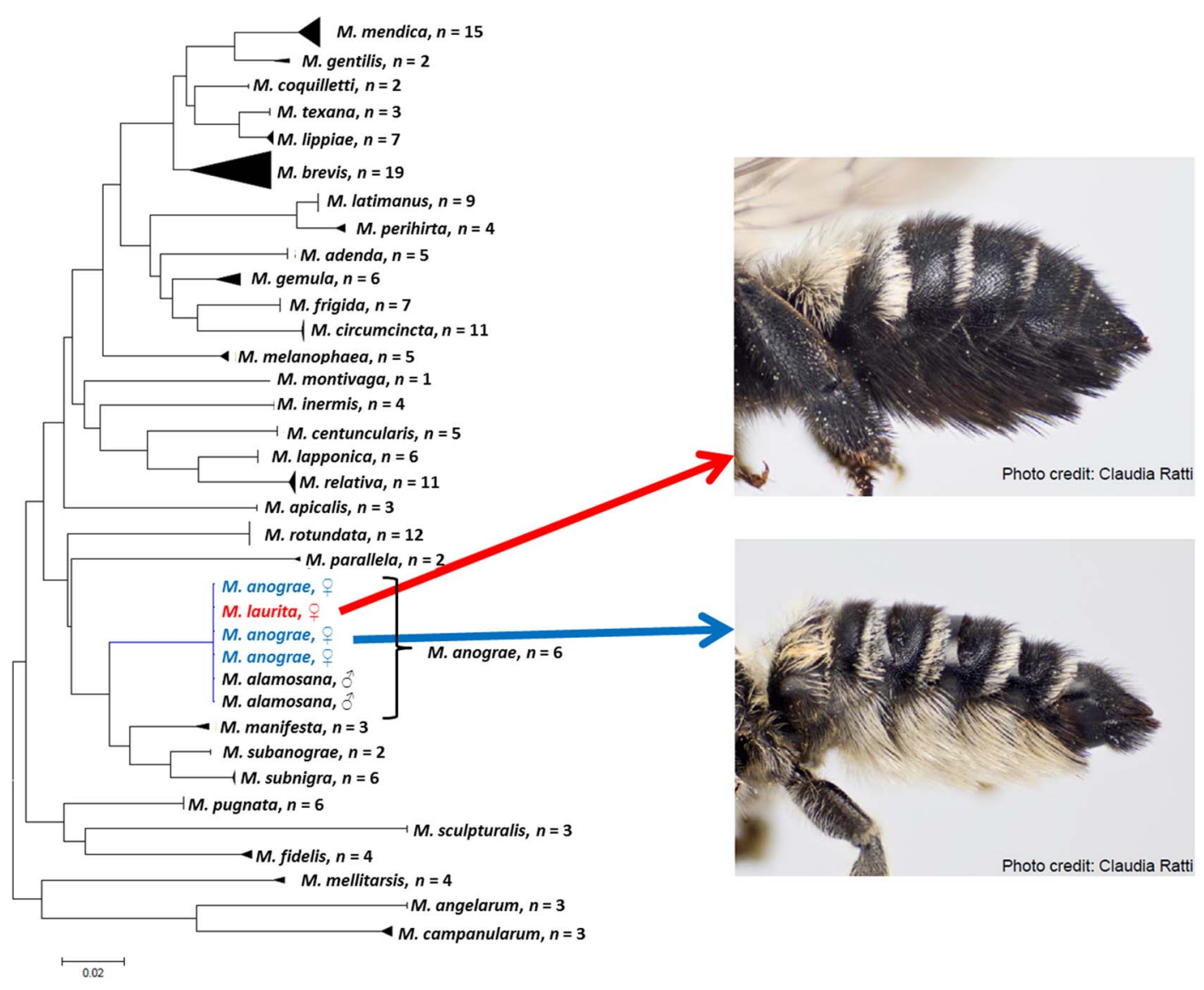

\section{Acknowledgements}

The authors thank Laurence Packer, York University, for his infectious obsession with bees, and for his support and encouragement for various studies of Canadian bees. Much of the initial financial support for graduate studies of Canadian bees came from Laurence through the Canadian Barcode of Life Network from Genome Canada (through the Ontario Genomics Institute), Natural Sciences and Engineering Research Council of Canada, and other sponsors listed at www. BOLNET.ca and via the National Science and Engineering Research Council (NSERC) Canadian Pollination Initiative (CANPOLIN).
Additional funding for specimens in the south Okanagan provided by the British Columbia Parks, Park Enhancement Fund, British Columbia Ministry of Environment and federal Habitat Stewardship Program Prevention Stream to J.H.; the Saskatchewan Ministry of Agriculture and the Canada-Saskatchewan Growing Forward 2 bilateral agreement, and the Earth Rangers "Bring Back the Wild" campaign, both to C.S.S. Thanks are due to Paul D.N. Hebert, University of Guelph, for his early and continuing encouragement for bee DNA barcoding work, and the Biodiversity Institute of Ontario, University of Guelph for tissue sample preparation and all laboratory work associated with DNA barcoding. 
Lastly, the authors thank all the individuals and institutions that have provided specimens for use in their studies.

\section{References}

Ascher, J.S. and Pickering, J. 2017. Discover life bee species guide and world checklist [online]. Available from www.discoverlife.org $/ \mathrm{mp} / 20 \mathrm{q}$ ?guide=Apoidea species\&flags=HAS [accessed 15 February 2017].

Bergsten, J., Bilton, D.T., Fujisawa, T., Elliott, M., Monaghan, M.T., Balke, M., et al. 2012. The effect of geographical scale of sampling on DNA barcoding. Systematic Biology, 61: 851-869.

Brown, M.J. and Paxton, R.J. 2009. The conservation of bees: a global perspective. Apidologie, 40: 410-416.

Bzdyk, E. 2012. A revision of the Megachile subgenus Litomegachile Mitchell with an illustrated key and description of a new species (Hymenoptera, Megachilidae, Megachilini). ZooKeys, 221: 31-61.

Canadian Endangered Species Conservation Council. 2016. Wild species 2015: the general status of species in Canada. National General Status Working Group, Ottawa, Ontario, Canada.

Carman, G.M. and Packer, L. 1996. A cryptic species allied to Halictus ligatus Say (Hymenoptera: Halictidae) detected by allozyme electrophoresis. Journal of the Kansas Entomological Society, 69: 168-176.

Carolan, J.C., Murray, T.E., Fitzpatrick, Ú., Crossley, J., Schmidt, H., Cederberg, B., et al. 2012. Colour patterns do not diagnose species: quantitative evaluation of a DNA barcoded cryptic bumblebee complex. Public Library of Science One, 7: e29251.

Carvalho, M.R., Ebach, M.C., Williams, D.M., Nihei, S.S., Trefaut Rodrigues, M., Grant, T., et al. 2014. Does counting species count as taxonomy? On misrepresenting systematics, yet again. Cladistics, 30: $322-329$.

Coelho, B.W.T. 2004. A review of the bee genus Augochlorella (Hymenoptera: Halictidae: Augochlorini). Systematic Entomology, 29: 282-323.

Collins, R.A. and Cruickshank, R.H. 2013. The seven deadly sins of DNA barcoding. Molecular Ecology Resources, 13: 969-975.

Collins, R.A. and Cruickshank, R.H. 2014. Known knowns, known unknowns, unknown unknowns and unknown knowns in DNA barcoding: a comment on Dowton et al. Systematic Biology, 63: 1005-1009.

Committee on the Status of Endangered Wildlife in Canada. 2014. COSEWIC assessment and status report on the western Bumble Bee Bombus occidentalis, occidentalis subspecies (Bombus occidentalis occidentalis) and the mckayi subspecies (Bombus occidentalis mckayi) in Canada. Committee on the Status of Endangered Wildlife in Canada. Ottawa, Ontario, Canada. Available from www. registrelep-sararegistry.gc.ca/document/default_e.cfm? documentID=969 [accessed 23 August 2017].
Committee on the Status of Pollinators in North America. 2007. Status of pollinators in North America. National Academic Press, Washington, District of Columbia, United States of America.

Danforth, B.N., Mitchell, P.L., and Packer, L. 1998. Mitochondrial DNA differentiation between two cryptic Halictus (Hymenoptera: Halictidae) species. Annals of the Entomological Society of America, 91: 387-391.

Danks, H.V. (editor) 1979. Canada and its insect fauna: an overview. Memoirs of the Entomological Society of Canada, 108: 1-573.

Danks, H.V. 2016. The Biological Survey of Canada: a personal history. Biological Survey of Canada Monograph Series, 8: 1-180.

Dolan, A.C., Delphia, C.M., O'Neill, K.M., and Ivie, M.A. 2017. Bumble bees (Hymenoptera: Apidae) of Montana. Annals of the Entomological Society of America, 110: 129-144.

Dowton, M., Meiklejohn, K., Cameron, S.L., and Wallman, J. 2014. A preliminary framework for DNA barcoding, incorporating the multispecies coalescent. Systematic Biology, 63: 639-644.

Droege, S., Rightmyer, M.G., Sheffield, C.S., and Brady, S.G. 2010. New synonymies in the bee genus Nomada from North America (Hymenoptera: Apidae). Zootaxa, 2661: 1-32.

Dumesh, S. and Sheffield, C.S. 2012. Bees of the genus Dufourea LePeletier (Hymenoptera: Halictidae: Rophitinae) of Canada. Canadian Journal of Arthropod Identification, 20: 1-36.

Francoso, E. and Arias, M.C. 2013. Cytochrome c oxidase I primers for corbiculate bees: DNA barcode and mini-barcode. Molecular Ecology Resources, 13: $844-850$.

Galimberti, A., De Mattia, F., Bruni, I., Scaccabarozzi, D., Sandionigi, A., Barbuto, M., et al. 2014. A DNA barcoding approach to characterize pollen collected by honeybees. Public Library of Science One, 9: p.e109363.

Gibbs, J. 2009. Integrative taxonomy identifies new (and old) species in the Lasioglossum (Dialictus) tegulare (Robertson) species group (Hymenoptera, Halictidae). Zootaxa, 2032: 1-38.

Gibbs, J. 2010. Revision of the metallic species of Lasioglossum (Dialictus) in Canada (Hymenoptera, Halictidae, Halictini). Zootaxa, 2591: 1-382.

Gibbs, J. 2011. Revision of the metallic Lasioglossum (Dialictus) of eastern North America (Hymenoptera: Halictidae: Halictini). Zootaxa, 3073: 1-216.

Gibbs, J. and Dathe, H.H. 2017. First records of Hylaeus (Paraprosopis) pictipes Nylander, 1852 (Hymenoptera: Colletidae) in North America. Check List, 13: 1-6.

Gibbs, J., Packer, L., Dumesh, S., and Danforth, B.N. 2013. Revision and reclassification of Lasioglossum (Evylaeus), L. (Hemihalictus) and L. (Sphecodogastra) in eastern North America (Hymenoptera: Apoidea: Halictidae). Zootaxa, 3672: 1-117.

Goldstein, P.Z. and DeSalle, R. 2011. Integrating DNA barcode data and taxonomic practice: determination, discovery, and description. Bioessays, 33: 135-147. 
Hajibabaei, M., Ivanova, N.V., Ratnasingham, S., Dooh, R.T., Kirk, S.L., Mackie, P.M., and Hebert, P.D.N. 2005. Critical factors for assembling a high volume of DNA barcodes. Philosophical Transactions of the Royal Society of London B: Biological Sciences, 360: 1959-1967.

Hajibabaei, M., Singer, G.A., Hebert, P.D.N., and Hickey, D.A. 2007. DNA barcoding: how it complements taxonomy, molecular phylogenetics and population genetics. TRENDS in Genetics, 23: $167-172$.

Hajibabaei, M., Smith, M., Janzen, D.H., Rodriguez, J.J., Whitfield, J.B., and Hebert, P.D.N. 2006. A minimalist barcode can identify a specimen whose DNA is degraded. Molecular Ecology Notes, 6: 959-964.

Hebert, P.D.N., Cywinska, A., Ball, S.L., and deWaard, J.R. 2003a. Biological identifications through DNA barcodes. Proceedings of the Royal Society B: Biological Sciences, 270: 313-322.

Hebert, P.D.N. and Humble, L.M. 2011. A comprehensive DNA barcode library for the looper moths (Lepidoptera: Geometridae) of British Columbia, Canada. Public Library of Science One, 6: e18290.

Hebert, P.D.N. and Landry, J.F. 2010. DNA barcodes for $1 / 1000$ of the animal kingdom. Biology Letters, 6: $359-362$.

Hebert, P.D.N., Ratnasingham, S., and de Waard, J.R. 2003b. Barcoding animal life: cytochrome c oxidase subunit 1 divergences among closely related species. Proceedings of the Royal Society of London B: Biological Sciences, 270(Supplement 1): S96-S99.

Hebert, P.D.N., Ratnasingham, S., Zakharov, E.V., Telfer, A.C., Levesque-Beaudin, V., Milton, M.A., et al. 2016. Counting animal species with DNA barcodes: Canadian insects. Philosophical Transactions of the Royal Society, Series B, 371: 20150333.

Hicks, B. 2009. Observations of nest structure of Osmia inermis (Hymenoptera: Megachilidae) from Newfoundland, Canada. Journal of the Acadian Entomological Society, 5: 12-18.

Hollingsworth, P.M., Graham, S.W., and Little, D.P. 2011. Choosing and using a plant DNA barcode. Public Library of Science One, 6: e19254.

Hurd, P.D. 1979. Superfamily Apoidea. In Catalog of Hymenoptera in America North of Mexico. Edited by K.V. Krombein, P.D. Hurd, D.R. Smith, and R.D. Burks. Smithsonian Institution Press, Washington, District of Columbia, United States of America. Pp. 1741-2209.

Köhler, F. 2007. From DNA taxonomy to barcoding how a vague idea evolved into a biosystematic tool. Mitteilungen aus dem Museum für Naturkunde in Berlin, Zoologische Reihe, 83: 44-51.

Kress, W.J. and Erickson, D.L. 2007. A two-locus global DNA barcode for land plants: the coding rbcL gene complements the non-coding trnH-psbA spacer region. Public Library of Science One, 2: e508.
Kress, W.J., García-Robledo, C., Uriarte, M., and Erickson, D.L. 2015. DNA barcodes for ecology, evolution, and conservation. Trends in Ecology \& Evolution, 30: 25-35.

Kress, W.J., Wurdack, K.J., Zimmer, E.A., Weigt, L.A., and Janzen, D.H. 2005. Use of DNA barcodes to identify flowering plants. Proceedings of the National Academy of Sciences of the United States of America, 102: 8369-8374.

Kumar, S., Stecher, G., and Tamura, K. 2016. MEGA7: Molecular Evolutionary Genetics Analysis version 7.0 for bigger datasets. Molecular Biology and Evolution, 33: 1870-1874.

Li, X., Yang, Y., Henry, R.J., Rossetto, M., Wang, Y., and Chen, S. 2015. Plant DNA barcoding: from gene to genome. Biological Reviews, 90: 157-166.

Lim, G.S., Balke, M., and Meier, R. 2012. Determining species boundaries in a world full of rarity: singletons, species delimitation methods. Systematic Biology, 61: 165-169.

MacIvor, J.S. 2016. DNA barcoding to identify leaf preference of leafcutting bees. Royal Society Open Science, 3: 150623. https://doi.org/10.1098/ rsos. 150623 .

Magnacca, K.N. and Brown, M.J. 2009. Tissue segregation of mitochondrial haplotypes in heteroplasmic Hawaiian bees: implications for DNA barcoding. Molecular Ecology Resources, 10: 60-68.

Magnacca, K.N. and Brown, M.J. 2010. Mitochondrial heteroplasmy and DNA barcoding in Hawaiian Hylaeus (Nesoprosopis) bees (Hymenoptera: Colletidae). BMC Evolutionary Biology, 10: 1-16.

Magnacca, K.N. and Brown, M.J. 2012. DNA barcoding a regional fauna: Irish solitary bees. Molecular Ecology Resources, 12: 990-998.

Martins, K.T., Normandin, É., and Ascher, J.S. 2017. Hylaeus communis (Hymenoptera: Colletidae), a new exotic bee for North America with generalist foraging and habitat preferences. The Canadian Entomologist, 149: 377-390.

Maurer, D. 2000. The dark side of taxonomic sufficiency (TS). Marine Pollution Bulletin, 40: 98-101.

Meier, R. and Dikow, T. 2004. Significance of specimen databases from taxonomic revisions for estimating and mapping the global species diversity of invertebrates and repatriating reliable specimen data. Conservation Biology, 18: 478-488.

Michener, C.D. 2007. The bees of the world, 2nd edition, Johns Hopkins Press, Baltimore, Maryland, United States of America.

Mitchell, T.B. 1960. Bees of the eastern United States. Volume I. North Carolina Agricultural Experiment Station Technical Bulletin, 141: 1-538.

Onuferko, T.M. 2017. Cleptoparasitic bees of the genus Epeolus Latreille (Hymenoptera: Apidae) in Canada. Canadian Journal of Arthropod Identification, 30: 1-62. https://doi.org/10.3752/cjai.2017.30.

Ordway, E. 1966. Systematics of the genus Augochlorella (Hymenoptera, Halictidae) north of Mexico. The University of Kansas Science Bulletin, 46: 509-624. 
Packer, L., Gibbs, J., Sheffield, C., and Hanner, R. 2009a. DNA Barcoding and the mediocrity of morphology. Molecular Ecology Resources, 9: 42-50.

Packer, L., Gibbs, J., Sheffield, C., and Kevan, P. 2008. Barcoding the bees of the world. In Anais do VIII Encontro sobre Abelhas, Biodiversidade e Uso Sustentado de Abelhas. Edited by D. De Jong, T.M. Francoy, and W.C. Santana. Fundação de Pesquisas Científicas de Ribeirão Preto, Ribeirão Preto, Brazil. Pp. 276-282.

Packer, L., Grixti, J.C., Roughley, R.E., and Hanner, R. 2009a. The status of taxonomy in Canada and the impact of DNA barcoding. Canadian Journal of Zoology, 87: 1097-1110.

Packer, L., Sheffield, C.S., Gibbs, J., de Silva, N., Best, L.R., Ascher, J., et al. 2009b. The campaign to barcode the bees of the world: progress, problems, prognosis. In Memorias VI Congreso Mesoamericano sobre Abejas Nativas. Edited by C.L.Y. Obiols. Universidad de San Carlos de Guatemala Centro de Estudios Conservacionistas, Antigua, Guatemala. Pp. 180-182.

Ratnasingham, S. and Hebert, P.D.N. 2007. BOLD: The barcode of life data system (http://www. barcodinglife.org). Molecular Ecology Notes, 7: 355-364.

Ratnasingham, S. and Hebert, P.D.N. 2013. A DNAbased registry for all animal species: the barcode index number (BIN) system. Public Library of Science One, 8: e66213.

Rehan, S.M. and Sheffield, C.S. 2011. Morphological and molecular delineation of a new species in the Ceratina dupla species-group (Hymenoptera: Apidae) of eastern North America. Zootaxa, 2873: 35-50.

Romankova, T. 2004. Ontario bees of the tribe Epeolini: Epeolus Latreille and Triepeolus Robertson (Hymenoptera: Apidae, Nomadinae). Journal of the Entomological Society of Ontario, 135: 87-99.

Rosenmeier, L. and Packer, L. 1993. A comparison of genetic variation in two sibling species pairs of haplodiploid insects. Biochemical Genetics, 31: 185-200.

Schmidt, S., Schmid-Egger, C., Morinière, J., Haszprunar, G., and Hebert, P.D.N. 2015. DNA barcoding largely supports 250 years of classical taxonomy: identifications for Central European bees (Hymenoptera, Apoidea partim). Molecular Ecology Resources, 15: 985-1000.

Sheffield, C.S., Dumesh, S., and Cheryomina, M. 2011a. Hylaeus punctatus (Hymenoptera: Colletidae), a bee species new to Canada with a review of other non-native species. Journal of the Entomological Society of Ontario, 142: 29-43.

Sheffield, C.S., Frier, S.D., and Dumesh, S. 2014. The bees (Hymenoptera: Apoidea, Apiformes) of the Prairies Ecozone, with comparisons to other grasslands of Canada. In Arthropods of Canadian grasslands (volume 4): biodiversity and systematics, part 2. Edited by D.J. Giberson and H.A. Cárcamo. Biological Survey of Canada, Ottawa, Ontario, Canada. Pp. 427-467.
Sheffield, C.S. and Genaro, J.A. 2013. A new species of Megachile (Litomegachile) from Cuba, the Antilles (Hymenoptera: Megachilidae). Journal of Melittology, 19: 1-17.

Sheffield, C.S., Hebert, P.D., Kevan, P.G., and Packer, L. 2009. DNA barcoding a regional bee (Hymenoptera: Apoidea) fauna and its potential for ecological studies. Molecular Ecology Resources, 9: 196-207.

Sheffield, C.S., Kevan, P.G., Smith, R.F., Rigby, S.M., and Rogers, R.E.L. 2003. Bee species of Nova Scotia, Canada, with new records and notes on bionomics and floral relations (Hymenoptera: Apoidea). Journal of the Kansas Entomological Society, 76: 357-384.

Sheffield, C.S., Kevan, P.G., Westby, S.M., and Smith, R.F. 2008. Diversity of cavity-nesting bees (Hymenoptera: Apoidea) within apple orchards and wild habitats in the Annapolis Valley, Nova Scotia, Canada. The Canadian Entomologist, 140: 235-249.

Sheffield, C.S. and Perron, J.-M. 2014. Annotated catalogue of the bees described by Léon Provancher (Hymenoptera: Apoidea: Apiformes). The Canadian Entomologist, 146: 117-169.

Sheffield, C.S., Pindar, A., Packer, L., and Kevan, P.G. 2013. The potential of cleptoparasitic bees as indicator taxa for assessing bee communities. Apidologie, 44: 501-510.

Sheffield, C.S., Ratti, C., Packer, L., and Griswold, T. 2011b. Leafcutter and mason bees of the genus Megachile Latreille (Hymenoptera: Megachilidae) in Canada and Alaska. Canadian Journal of Arthropod Identification, 18: 1-107.

Sheffield, C.S., Richards, M., and Griswold, T. 2010. Discovery of the Old World bee, Megachile (Pseudomegachile) ericetorum (Hymenoptera: Megachilidae), in Ontario, Canada. Journal of the Entomological Society of Ontario, 141: 85-92.

Sheffield, C.S., Richardson, L., Cannings, S., Ngo, H., Heron, J., and Williams, P.H. 2016. Biogeography and designatable units of Bombus occidentalis Greene and B. terricola Kirby (Hymenoptera: Apidae) with implications for conservation status assessments. Journal of Insect Conservation, 20: 189-199. https://doi.org/10.1007/s10841-016-9853-2.

Sheffield, C.S. and Westby, S.M. 2007. The male of Megachile nivalis Friese, with an updated key to members of the subgenus Megachile s. str. (Hymenoptera: Megachilidae) in North America. Journal of Hymenoptera Research, 16: 178-191.

Sheffield, C.S. and Williams, P.H. 2011. Discovery of Bombus distinguendus (Hymenoptera: Apidae) in continental North America. Journal of the Entomological Society of Ontario, 142: 53-56.

Shokralla, S., Zhou, X., Janzen, D.H., Hallwachs, W., Landry, J.F., Jacobus, L.M., and Hajibabaei, M. 2011. Pyrosequencing for mini-barcoding of fresh and old museum specimens. Public Library of Science One, 6: e21252.

Slowik, J. and Blagoev, G.A. 2012. A survey of spiders (Arachnida: Araneae) of Prince of Wales Island, Alaska; combining morphological and DNA barcode identification techniques. Insecta Mundi, 251: 1-12. 
Smith, M.A., Fernandez-Triana, J., Roughley, R., and Hebert, P.D.N. 2009. DNA barcode accumulation curves for understudied taxa and areas. Molecular Ecology Resources, 9: 208-216.

Smith, M.A., Fisher, B.L., and Hebert, P.D.N. 2005. DNA barcoding for effective biodiversity assessment of a hyperdiverse arthropod group: the ants of Madagascar. Philosophical Transactions of the Royal Society B: Biological Sciences, 360: 1825-1834.

Soltis, P.S. and Gitzendanner, M.A. 1999. Molecular systematics and the conservation of rare species. Conservation Biology, 13: 471-483.

Spooner, D.M. 2009. DNA barcoding will frequently fail in complicated groups: an example in wild potatoes. American Journal of Botany, 96: 1177-1189.

Stahlhut, J.K., Fernández-Triana, J., Adamowicz, S.J., Buck, M., Goulet, H., Hebert, P.D.N., et al. 2013. DNA barcoding reveals diversity of Hymenoptera and the dominance of parasitoids in a sub-Arctic environment. BMC Ecology, 13: 2. Available from www.biomedcentral.com/1472-6785/13/2 [accessed 23 August 2017].

Trunz, V., Packer, L., Vieu, J., Arrigo, N., and Praz, C.J. 2016. Comprehensive phylogeny, biogeography and new classification of the diverse bee tribe Megachilini: can we use DNA barcodes in phylogenies of large genera? Molecular Phylogenetics and Evolution, 103: 245-259.

Valentini, A., Miquel, C., and Taberlet, P. 2010. DNA barcoding for honey biodiversity. Diversity, 2: 610-617.

Valentini, A., Pompanon, F., and Taberlet, P. 2009. DNA barcoding for ecologists. Trends in Ecology \& Evolution, 24: 110-117.

Vamosi, J.C., Gong, Y.B., Adamowicz, S.J., and Packer, L. 2016. Forecasting pollination declines through DNA barcoding: the potential contributions of macroecological and macroevolutionary scales of inquiry. New Phytologist, 213: 11-18. https://doi. org/10.1111/nph.14356.
Vickruck, J.L., Rehan, S.M., Sheffield, C.S., and Richards, M.H. 2011. Nesting biology and barcode analysis of two cryptic species within Ceratina dupla, with comparisons to $C$. calcarata (Hymenoptera: Apidae: Xylocopinae). The Canadian Entomologist, 143: 254-262.

Williams, P.H., Brown, M.J.F., Carolan, J.C., An, J., Goulson, D., Aytekin, A.M., et al. 2012. Unveiling cryptic species of the bumblebee subgenus Bombus s. str. world-wide with COI barcodes (Hymenoptera: Apidae). Systematics and Biodiversity, 10: 21-56.

Williams, P.H., Byvaltsev, A.M., Cederberg, B., Berezin, M.V., Ødegaard, F., Rasmussen, C., et al. 2015. Genes suggest arctic bumblebees combine morphologically cryptic species with ancestral colour polymorphisms that cut across species. Public Library of Science One, 10: e0144544. https://doi. org/10.1371/journal.pone.0144544.

Williams, P.H., Cannings, S.G., and Sheffield, C.S. 2016. Cryptic subarctic diversity: a new bumblebee species from the Yukon and Alaska (Hymenoptera, Apidae). Journal of Natural History, 50: $45-46$.

Williams, P.H., Thorp, R.W., Richardson, L.L., and Colla, S.R. 2014. Bumble bees of North America: an identification guide. Princeton University Press, Princeton, New Jersey, United States of America.

Zahiri, R., Lafontaine, J.D., Schmidt, B.C., Zakharov, E.V., and Hebert, P.D.N. 2014. A transcontinental challenge - a test of DNA barcode performance for 1,541 species of Canadian Noctuoidea (Lepidoptera). Public Library of Science One, 9: e92797.

Zahiri, R., Lafontaine, J.D., Schmidt, B.C., Zakharov, E.V., and Hebert, P.D.N. 2017. Probing planetary biodiversity with DNA barcodes: the Noctuoidea of North America. Public Library of Science One, 12: e0178548. 